\title{
Conceptions of National Identity and Ambivalence towards Immigration
}

\author{
Emmy Lindstam, Matthias Mader and Harald Schoen \\ School of Social Sciences, University of Mannheim \\ *Corresponding author: Email: elindsta@mail.uni-mannheim.de
}

(Received 6 February 2018; revised 26 July 2018; accepted 16 October 2018; First published online 1 July 2019)

\begin{abstract}
National identities are often conceived of as factors that lend structure and stability to citizens' political opinions on issues such as immigration. While citizens who define national membership in ethno-cultural terms are less likely to support immigration, those with a civic conception are more likely to do so. The authors propose that defining national identity along both ethno-cultural and civic lines may give rise to conflicting considerations, leading people to experience ambivalence, implying that national identities may serve less as a stabilizing force than suggested by previous research. Findings from heterogeneous choice models and a unique survey experiment show that German citizens with mixed conceptions of national identity had more variable and more malleable opinions than individuals with ideal-type conceptions during the 2015/2016 European refugee crisis. The findings point to an identity-based source of ambivalence and extend current understandings of how people form attitudes towards immigration.
\end{abstract}

Keywords national identities; ambivalence; refugees; immigration; public opinion

In an era of international economic exchange and mass migration, national boundaries become both permeable and contested. International co-operation and migration cross and highlight national borders and have the potential to invoke national identities as a force that drives citizens' opinion formation. It is thus little wonder that national identities have experienced a renaissance in public opinion research. Examples include research on support for regional integration (Carey 2002; Hooghe and Marks 2005) and disintegration (Clarke, Goodwin and Whiteley 2017), free trade agreements (Mayda and Rodrik 2005; O'Rourke and Sinnott 2001; Rankin 2001), attitudes towards the welfare state (Wright and Reeskens 2013), immigration (Citrin and Sides 2008; Esses et al. 2006) and tolerance of ethnic diversity (Citrin and Sears 2014).

When considering the role of national identities as a source of political attitudes, prior research often distinguishes between two ideal-typical notions of national identity: civic and ethno-cultural understandings (Bonikowski and DiMaggio 2016; Kunovich 2009; Theiss-Morse 2009; Wright, Citrin and Wand 2012). Since the former draws a soft boundary between the national in-group and out-groups and the latter a hard one, citizens with different notions of what it means to be a member of the nation are likely to have different preferences on a range of issues. As identities are unlikely to change quickly, national identities are often conceived of as factors that lend structure and stability to citizens' political opinions (Bonikowski and DiMaggio 2016; Jones and Smith 2001; Wagner et al. 2012). Given this stabilizing effect, the influence of national identities on political opinion may constrain elites' discretion in policy making, at least in the short term.

This line of reasoning may give rise to an overly static view of citizens' attitudes and elite policy making. Many studies point out that most people embrace ideas of both ideal-typical conceptions of national identity (Bonikowski and DiMaggio 2016; Kunovich 2009; Wright, Citrin 
and Wand 2012). However, this fact rarely translates into clear theorizing about the implications of such mixed conceptions on policy opinions. It is usually implicitly assumed that citizens derive some sort of average implication from the mix of civic and ethno-cultural norms that they have internalized. In contrast, we argue that subscribing to both civic and ethno-cultural norms at the same time can produce conflicting, irreconcilable considerations, thereby resembling values (Alvarez and Brehm 2002; Rudolph 2005) or partisan orientations (Basinger and Lavine 2005; Lavine 2001). If both types of norms are psychologically salient, citizens may be unable to reconcile civic and ethno-cultural norms. Invoking national identities thus does not necessarily make citizens' responses towards policy proposals and events more stable and predictable. Rather, some people may feel torn and have a hard time making up their mind. Endorsing conflicting considerations also renders political opinions contextually dependent on what considerations are momentarily salient (Lavine 2004). Accordingly, individuals who subscribe to both civic and ethno-cultural understandings of national identity are likely to be more malleable, that is, to switch back and forth in their opinions as a function of what considerations are made salient in public debate. If the impact of national identity can increase, rather than decrease, the malleability of citizens' opinions, political elites have more leeway in policy making on issues that touch upon conceptions of national identity than previously thought.

In this article, we explore how German citizens' different conceptions of national identity can help us understand opinion formation regarding the recent European refugee protection crisis. The issue of immigration is a case in point; the influx of refugees is likely to touch on rivalling notions of what the nation is and ought to be. The arrival of newcomers may be seen as dissonant with an ethno-cultural conception that implies defining refugees as 'outsiders'. At the same time, showing solidarity with those in need may be seen as consonant with a civic conception that includes humanitarian norms. Holding mixed conceptions of national identity may therefore give way to conflicting considerations about immigration and refugees, leading to fickle and changing opinions on these issues. The German case is, in turn, particularly well suited to study the issue at hand. The country is a textbook example of an 'ethno-cultural' nation (Kohn 1944) with a history of exclusive national membership regimes (Brubaker 1992). At the same time, a civic notion of national identity plays a central role in German post-war elite discourse (Habermas 1990; Müller 2009) and is deeply ingrained in many citizens' understandings of what it means to be a German (Ariely 2011; Mader 2016). It is thus reasonable to expect that significant portions of the German population subscribe to conflicting ideas of national identity. Moreover, Germany was the main European destination of refugees in 2015 and 2016. The influx of refugees fuelled a public discourse that was likely to make people aware of the diversity of identity-related ideas, as public debates attracted the attention of virtually all citizens in Germany. While opponents of the influx of refugees pointed to ethnic and cultural differences, elites pleading for a liberal stance stressed humanitarian ideas that underlie civic notions of German national identity.

Studying individual-level data from two different surveys, employing a survey experiment and a panel set-up, we find that attitudes towards immigration are more positive (negative) among those who have a civic (ethno-cultural) conception of the nation, and that opinions are less stable and more malleable among those who believe both ethno-cultural and civic criteria matter. This implies that national identities may serve less as a stabilizing force than suggested by previous research, an important possibility given that many recent events and political debates hint at both civic and ethno-cultural notions of national identity. Public opinion may therefore represent less of a constraint on elite decision making than suggested by conventional wisdom; elite politics on identityrelated issues not only reflect deeply held convictions, but are also effective at shaping public opinion.

\section{National Identities and Attitudes Towards Immigration}

Conceptions of national identity have often been found to be strong determinants of attitudes towards outsiders (Esses et al. 2006; Weldon 2006), and are generally thought to help people 
solve dilemmas when forming attitudes towards immigration. Cross-cultural research has tried to identify recurring themes in how citizens normatively conceptualize the nation. The most common theme is the well-known ethno-cultural/civic distinction (Kohn 1944; Smith 1991), which refers to different ways of drawing 'the circle of we' (Hollinger 2006). Accordingly, citizens define group boundaries in terms of either ethno-cultural or civic criteria. Having a civic conception of the nation involves seeing group membership as a function of accepting certain political values and institutions (Wright, Citrin and Wand 2012, 471). In the case of the United States, for example, one tradition of defining the nation relies on a liberal creed of universalism, tolerance, equality of opportunity and the rule of law (Bonikowski and DiMaggio 2016; Citrin, Reingold and Green 1990). Similarly, in Germany the notion of 'constitutional patriotism' prescribes citizens to reject authoritarianism and to embrace democratic principles (Habermas 1990; Müller 2009). Since these characteristics are achievable in the sense that individuals can actively adopt them, boundaries drawn using these criteria are permeable for outsiders. In contrast, ethno-culturalism is defined as the belief that the boundaries of the nation are defined by ethnic and cultural markers which cannot be (easily) transcended: 'Genealogy and presumed descent ties, popular mobilization, vernacular languages, customs and traditions: these are the elements of an alternative, ethno-cultural conception of the nation' (Smith 1991, 12). Certainly, the distinction of ethno-cultural versus civic conceptions of the nation is an idealized one. Most citizens will subscribe to a mix of both criteria, and prioritize one of the two dimensions. ${ }^{1}$

How do conceptions of national identity explain attitudes towards immigration? According to social identity theory, categorizing people into out-groups and in-groups stimulates a motivation to maintain a positive sense of group distinctiveness (Tajfel and Turner 1979). When group identity is salient, prejudice against out-groups may become particularly evident, especially if there is a threat to in-group identity (Branscombe et al. 1999; Esses et al. 2006). In line with this argument, research shows that a perceived symbolic threat towards the in-group is an important driver of immigration attitudes (McLaren 2003; Sides and Citrin 2007; Sniderman, Hagendoorn and Prior 2004). Since citizens who hold an ethno-cultural view of national identity define the nation in a way that excludes immigrants (Pehrson, Vignoles and Brown 2009), such citizens should also be more likely to feel threatened by immigrants and thus hold more negative attitudes towards immigration. From an ethno-cultural point of view, immigrants can never assume the criteria necessary to become in-group members - ethnicity in particular is not achievable. The degree of opposition toward immigration among ethno-cultural nationalists should, in turn, be conditional on the (dis)similarity between members of the receiving country and immigrants in ethnic or cultural terms. ${ }^{2}$

Having a civic conception of the nation, however, may imply a more open and inclusive understanding of what it means to be part of the national in-group. Crucially, the civic criteria can be acquired, and thus do not pose an insurmountable obstacle between in-group and (current) out-group members. At least in theory, immigrants can move quickly from the outgroup to the in-group by acquiring the necessary qualities. This means that citizens with a civic conception should feel less threatened by immigrants than citizens with an ethno-cultural conception. In contexts where democratic and humanistic values are part of the civic narrative, it

\footnotetext{
${ }^{1}$ Shulman (2002) has suggested that it might be necessary to distinguish between three dimensions - ethnic, cultural and civic - to adequately capture the normative conceptions in European publics. By and large, however, survey research has shown that civic and ethno-cultural conceptions are identifiable dimensions in citizens' national identities in most publics (Jones and Smith 2001; Kunovich 2009; Reeskens and Hooghe 2010). We therefore draw on this conceptual distinction while acknowledging the debates about its analytical usefulness and empirical appropriateness (e.g., Kuzio 2002; Janmaat 2006; Larsen 2017).

${ }^{2} \mathrm{We}$ are unaware of research that addresses this question, however. Evidence from the American public suggests that while ethno-culturally dissimilar potential immigrants are seen more critically, this pattern is largely stable across different segments of the receiving society, including citizens who differ in their level of ethnocentrism (Hainmueller and Hopkins 2015).
} 
is also likely that having a clearly civic conception of national identity increases tolerance vis-à-vis those who do not set any criteria for national membership. Following the social identity approach, individuals who identify with the nation are expected to conform to in-group norms. Holding a civic understanding of the nation would then prescribe tolerance, as humanistic duties and obligations are attached to their definition of national identity. Note that this mechanism goes beyond a value-based explanation, as it posits that it is social identity that primes the civic values and increases the motivation to reach a conclusion in line with these values, given individuals' need for social approval and acceptance.

Empirical findings regarding the impact of civic conceptions on tolerance have been mixed, however (Citrin and Wright 2008; Schildkraut 2007). This might be attributed to measurement errors (Wright, Citrin and Wand 2012), but could also be due to the fact that a civic conception of the nation can also serve as a basis on which to exclude newcomers who are not perceived to embrace values associated with the nation. For instance, the portrayal of political Islam as irreconcilable with liberal values sometimes serves to justify opposition against Muslim immigration (Kinnvall and Nesbitt-Larking 2011). This argument resonates with the more general point that political entrepreneurs at least to some extent draw on the same set of symbolic resources to construct and defend both exclusive and inclusive conceptions of national identity (Zimmer 2003). Against this backdrop, expectations regarding the effect of the civic conception of national identity on immigration attitudes are not self-evident. However, where humanistic values are part of the civic narrative, and where public discourse draws on the civic conception of national identity to advocate tolerance and solidarity with outsiders, we expect individuals who prioritize civic criteria of national membership to be more supportive of immigration.

Hypothesis 1a: The more important ethno-cultural criteria are for individuals' conceptions of national identity, the more likely they are to oppose immigration.

Hypothesis 1b: The more important civic criteria are for individuals' conceptions of national identity, the more likely they are to support immigration.

\section{National Identities and Ambivalence}

Up until this point we have discussed the implications of the two conceptions in isolation from one another. As noted above, however, the ethno-cultural and civic conceptions should be understood as ideal types. Indeed, previous empirical research has demonstrated that many people do not have an exclusively ethno-cultural or civic understanding of national identity, but subscribe to a mix of the two (Bonikowski and DiMaggio 2016; Kunovich 2009; Wright, Citrin and Wand 2012). Defining national identity in both ethno-cultural and civic terms is not in itself a contradiction; rather, it seems quite likely that many individuals understand national membership both as a function of sharing deep cultural and ancestral traits and ascribing to certain civic norms and values. However, if holding an ethno-cultural conception of national identity increases opposition to immigration and a civic conception increases support for immigration, a mixed conception of national identity may easily give rise to conflicting considerations regarding immigration.

If it is true that citizens derive rivalling considerations about immigration from ethno-cultural and civic conceptions of the nation, what does that imply for opinion formation among citizens with mixed conceptions? We draw on the rich literature on ambivalence to address this question. Ambivalence has been broadly defined as an individual's endorsement of competing considerations relevant to the evaluation of an attitude object (Lavine 2001, 915). Ambivalent individuals have not only one, but several considerations to take into account when evaluating policy issues. Crucially, these considerations are not one sided but might lead individuals 'to decide the issue either way' (Zaller and Feldman 1992, 585). Ambivalence has several important 
implications for attitude formation on policy issues, in particular with regard to the stability and malleability of policy preferences. As Lavine puts it, ambivalence 'renders the political choice process excessively difficult and unreliable [...] and contextually dependent on whatever relevant considerations are momentarily salient' (Lavine 2004, 94). We suggest that these implications also hold for immigration attitudes among citizens who understand national membership as a function of both sharing deep cultural and ancestral traits and subscribing to certain civic norms and values. ${ }^{3}$

First then, holding mixed conceptions of the nation may give rise to unstable and volatile policy opinions. Individuals may feel internally conflicted and torn between competing considerations anchored in their understanding of national identity. ${ }^{4}$ Seeing merit on both sides of the argument, they may find it 'difficult to reach a policy decision because they may be unwilling or unable to sacrifice one value for the sake of the other' (Rudolph and Popp 2007, 911). In this specific case, the wish to show tolerance and solidarity with immigrants in need (a consideration based on the civic conception) and the wish to protect the national in-group from negative societal change (a consideration based on the ethno-cultural conception) may be extremely difficult to reconcile. Facing such internal conflict, such individuals are unlikely to average across the positive and negative considerations, which would result in a relatively moderate and stable opinion. Torn between rivalling considerations, they are more likely to randomly come down on one side of the issue or the other (Alvarez and Brehm 2002; Keele and Wolak 2006; Steenbergen and Brewer 2004). We therefore expect unstable and changing attitudes, or variable attitudes, to be common among individuals who have mixed conceptions of national identity.

Hypothesis 2: Individuals who believe both ethno-cultural and civic criteria matter for national membership exhibit greater variability in immigration attitudes than individuals who have ideal-type conceptions of national membership.

Our concept of variability refers to intrinsic instability, or put differently, variability in the absence of external factors. This type of variability is a reflection of the inherent difficulty people face when shaping opinions while experiencing internal conflict. However, this is unlikely to be the only source of attitude instability; attitudes among individuals with mixed conceptions of national identity may also be more sensitive to external stimuli - and thereby be more malleable. When forming an opinion, individuals tend to retrieve from long-term memory whichever considerations are recently activated or at the 'top of the head' (Zaller and Feldman 1992). Individuals who hold both positive and negative considerations about an attitude object are therefore likely to sway back and forth in their overall opinion depending on which considerations are most salient in their mind. ${ }^{5}$ Crucially, the importance of salience in the process of

\footnotetext{
${ }^{3}$ Some individuals do not establish any criteria for national membership. Such individuals do not believe ethno-cultural criteria are necessary for in-group membership. Therefore, they have a potentially inclusive view. At the same time, they are less likely to feel that they, as citizens, have any particular civic obligations. These individuals are not likely to be ambivalent, but opinion formation may be difficult due to the (potential) absence of guiding principles and criteria. Some authors describe such individuals as indifferent (Lavine 2001; Rudolph 2005; Thornton 2011). As Thornton (2011, 865) puts it, 'rather than experiencing internal conflict, some individuals have little to no reaction to political stimuli. Neither ambivalent, nor one-sided, these individuals are indifferent'. Although open to debate, we believe these individuals are more likely to be 'indifferent' or show 'non-attitudes' when asked to respond to questions about refugees than citizens with ideal-type identities.

${ }^{4}$ This kind of internalized conflict is sometimes referred to as 'felt' or 'subjective ambivalence', which in turn derives from 'potential' or 'objective ambivalence' - simultaneously holding positive and negative feelings towards an attitude object (Albertson, Brehm and Alvarez 2005; Newby-Clark, McGregor and Zanna 2002). Using this terminology we propose that holding mixed conceptions of the nation is likely to generate conflicting considerations about an issue (objective ambivalence). Under certain circumstances, this may lead individuals to experience an internal conflict (subjective ambivalence), which renders opinion formation more difficult.

${ }^{5}$ In order for attitudes to be malleable, it is not necessary that the individual feels conflicted. The individual may be more or less aware of the contradictions stemming from different considerations. Variability and malleability are thus two separate
} 
sampling considerations opens up the possibility of elite influence on attitude formation. As Sniderman and Theriault $(2004,139)$ point out, 'just so far as citizens find themselves up in the air, ready to vote thumbs up or thumbs down, the intervention of elites is pivotal'. The framing of policy issues, in particular, may become highly consequential as this affects which considerations individuals are likely to have at the top of their minds when they determine their preference. According to this logic, individuals who hold mixed conceptions of national identity may sway back and forth in their opinion, depending on whether arguments related to tolerance and solidarity or the protection of the national in-group are most salient in the public debate. In sum, we expect that individuals who hold mixed conceptions of national identity will have more malleable immigration attitudes.

Hypothesis 3: Individuals who believe both ethno-cultural and civic criteria matter for national membership have more malleable immigration attitudes than individuals who have ideal-type conceptions of national membership.

\section{The Case: German Public Attitudes During the Refugee Crisis}

Exploring the role of ambivalence induced by different notions of the nation requires a careful selection of cases, both in terms of the issue and the information context under consideration. For instance, whether or not individuals with mixed conceptions of the nation will experience unease and feel torn about policy issues is likely to depend on the nature of the issue at hand and the accompanying public discourse. Issues such as regional integration, international cooperation and immigration touch upon different conceptions of the nation and may thus invoke national identities in opinion formation. By the same token, identity-induced ambivalence may make opinions less stable and predictable. Issues can be framed quite differently in public discourse, however. If public discourse focuses on one conception of the nation, people may be unaware that another conception they also subscribe to implies a contradictory evaluation of the issue in question. In such cases, opinions are unlikely to become more unstable and volatile. Provided public discourse highlights both ethno-cultural and civic notions of the nation, by contrast, embracing both of these notions of what constitutes a nation should make feelings of ambivalence and hence uncertainty in opinion formation more widespread.

In order to examine the validity of our novel conjecture about the impact of conflicting implications of different ideas about the nation, we analyse German public attitudes towards immigration in the context of the influx of refugees from crisis-stricken regions in Northern Africa and the Middle East into European countries in 2015 and 2016. By risking their lives on the dangerous journey over the Mediterranean Sea or via the land route through the Balkans, these refugees elicit considerations that touch upon both ethno-cultural and civic conceptions. More specifically, the issue of how to deal with the situation directly touches upon the ethnocultural in-group/out-group distinction as well as perceptions of civic obligations. Individuals who embrace ideas from both ideal-type conceptions are likely to feel torn about how to best deal with the refugee crisis, as conflicting considerations such as the wish to protect the national ingroup from the influx of ethno-culturally different outsiders, and the wish to show solidarity with those in need, enter into conflict. Opinions on how to deal with the refugee crisis are therefore particularly well suited to exploring the potential effects of ambivalence on attitude formation.

As for studying German attitudes, Germany was the main destination of refugees in this period: the country received about 890,000 asylum seekers in 2015 (BMI 2016). The influx triggered polarized public debates and became the most important issue for a large number of

implications derived from endorsing conflicting considerations that may or may not occur simultaneously. The distinguishing criterion is the presence vs. absence of external stimuli. While variability refers to intrinsic instability, or variability in the absence of external factors, malleability refers to the influence of external factors on opinions. 
citizens (Kratz and Schoen 2017). In the early stages, champions of a liberal stance on immigration and a civic notion of nationhood pointed to the moral obligation to help refugees in distress on the Mediterranean Sea even if this increased the number of arrivals to Germany. Later, when the refugees began to take the land route via the Balkans and the number of people reaching Germany markedly increased, they supported the government's decision to let many refugees enter the country and not to strictly rely on the Dublin Regulation. ${ }^{6}$ Quite quickly, proponents of an ethno-cultural notion of nationhood came up with a fierce critique of this policy, referring to order and social cohesion. In effect, elite discourse highlighted both ethnocultural and civic considerations (Chouliaraki et al. 2017; Haller 2017; Holmes and Castañeda 2016; Mushaben 2017; Trauner and Turton 2017).

The lively debate reflects the fact that Germany has long been considered a textbook example of an ethno-culturally defined nation that also embraces humanitarian norms as part of its civic narrative. Until the end of the 1990s Germany had one of the purest ius sanguinis regimes in Europe, meaning that only persons who had German ancestors could become Germans (Brubaker 1992). The liberal founders of the German post-war constitution did not abolish the ancestral citizenship principle, which dated back to 1842, believing that the referral to ethnocultural bonds would guarantee national stability and continuity in a war-devastated country (Kurthen 1995).

While Germany experienced a constant inflow of immigrants after World War II, its citizenship policy was reformed only in 2000, allowing second-generation immigrants to obtain citizenship regardless of their ancestry (Green 2013). This reform in a sense reflected the strong intellectual tradition of 'constitutional patriotism' after World War II, prescribing that the object of national identification should not be an ethno-culturally defined community but the constitution of the Federal Republic, with its democratic and humanitarian principles (Habermas 1990; Kronenberg 2013). Although these ideas - that have guided official German political culture and policies in various domains (Miller-Idris and Rothenberg 2012; Wittlinger 2010) finally shaped immigration policy, the ethno-cultural vision still resonates through German society, as indicated by the conflicts regarding questions such as whether Germany needs a Leitkultur (roughly: defining culture) and whether 'Islam belongs to Germany' (Becker 2017; Pautz 2005). ${ }^{7}$ These characteristics make Germany an ideal test case, as it provides a societal context in which both civic and ethno-cultural conceptions of the nation are socially represented. Ambivalence induced by embracing civic and ethno-cultural norms should thus be found in significant pockets of society.

\section{Research Design}

We test our hypotheses using two data sources. First, we analyse data from an online survey on foreign and security policy issues administered from 9 to 24 July 2015. The sample of respondents $(n=2,517)$ was drawn from the YouGov panel, which consists of German residents who have agreed to receive online surveys. The sampling process is designed to draw samples that approximate probability samples (Rivers 2006) by matching respondents on known demographic characteristics (gender, age, education and region). This information was also used to create a post-sampling weight, which we use in the analysis. ${ }^{8}$ Second, we replicate our findings using data

\footnotetext{
${ }^{6}$ The Dublin Regulation is an EU law that specifies that, in principle, the state through which an asylum seeker first entered the EU is responsible for handling his or her application for asylum.

${ }^{7} \mathrm{We}$ acknowledge that strong ethnic arguments have been rare in past German discourses about national identity, but they have become more frequent with the rise of the Alternative für Deutschland and during the interim success of the Patriotic Europeans Against the Islamization of the Occident movement. These actors frequently used both ancestry and cultural markers, such as a Judeo-Christian heritage and German manners and norms, to advocate an exclusionist policy. Supporters of an inclusionist policy, in contrast, used explicit counter-frames that drew on the 'symbolic resources' of the civic conception.
} 
from the 2017 campaign panel survey of the German Longitudinal Election Study (GLES). We draw on its first wave, which included items on national identity and a suitable item on immigration (and relevant control variables), and six subsequent waves that included the immigration item again. These waves were in the field between October 2016 and September 2017. Of the 15,802 respondents newly recruited for the first wave, 6,123 participated in all seven waves (39 per cent). The sample was drawn from the Respondi and Gapfish open access panels. Like in the case of the YouGov survey, respondents were drawn by matched quota sampling accounting for gender, age, education and region. Again, this information was also used to create a post-sampling weight, which we use in the analysis. For more details see the table in the appendix and the documentation to the official data file (Roßteutscher et al. 2018).

To measure respondents' conceptions of the nation, we follow the general strategy of previous research (Citrin, Reingold and Green 1990; Wright, Citrin and Wand 2012) and use items from a battery that asks respondents how important they think certain aspects are 'for being a true German'. The nine items used (see Table 1) cover ethnic, cultural and civic criteria and are specifically designed to tap into the different normative conceptions. ${ }^{9}$ We estimate an exploratory structural equation model (ESEM) to examine the dimensional structure of the responses (Asparouhov and Muthén 2009; Marsh et al. 2014). The global model fit and factor loadings are reported in Table 1. Accordingly, two-dimensional models describe the data well, in line with the theoretical arguments presented above. ${ }^{10}$ Using the regression method, we calculate factor scores on the basis of the ESEM and rescaled these scores to range from 0 to 1 . Table 2 reports the bivariate distribution of the two measures, which we dichotomized for this purpose. The top left cell shows that a substantial share of the German public (36/42 per cent) embraces both ethnocultural and civic norms and may experience ambivalence when it comes to evaluating immigration.

To assess opinions on immigration, we draw on an item that asked whether 'Germany should make more efforts to help refugees in distress at sea [even if more refugees would then come to Germany].' The item refers to a policy topic that was highly salient at the time (Kratz and Schoen 2017) and is likely to touch on both civic and ethno-cultural considerations. The wording of the item includes an experimental variation; the sample was randomly split in half, with one half rating the statement including the phrase in brackets and the other half rating an item excluding the phrase. We elaborate on the use of this experimental variation at the end of this section. In both cases, answers were given on a scale from 1-5 ( $1=$ 'Completely agree'; $5=$ 'Don't agree at all'). To capture attitudes about immigration with the GLES data we use an item asking respondents more directly whether they believe immigration should be facilitated or restricted. Responses were given on a 7-point scale. Replicating our findings with these data allows us to more thoroughly test the robustness of our results. German question wording and descriptive statistics can be found in the appendix.

\section{Measuring Variability}

As described, one implication of holding mixed conceptions of national identity is that it may lead to internalized conflict regarding issues that touch on rivalling considerations stemming

\footnotetext{
${ }^{8}$ Data collection was administered by Thomas J. Scotto and Jason Reifler. We thank these researchers for agreeing to include the national identity battery and the refugee item and sharing the data with us. Additional information on response rates and incentives for this and the other data source can be found in the appendix.

${ }^{9}$ The fact that the survey items were designed explicitly to cover these theoretically defined conceptions means that we can be more confident that we capture the constitutive elements than research that draws on the valuable (yet, in this respect, somewhat limited) International Social Survey Programme national identity data.

${ }^{10}$ In contrast, one-dimensional models are clearly inappropriate, as indicated by unacceptable model fit parameters (see the appendix). Allowing for a third dimension improves the model fit, but two of the three dimensions - those comprising the ethnic and cultural criteria, respectively - are highly correlated (with about 0.70 in the 2015 Yougov data and 0.80 in the 2016 GLES data). We therefore rely on the two-dimensional solution here.
} 
Table 1. National identity items, unstandardized factor loadings and factor correlations from an exploratory structural equation model

\begin{tabular}{lrrrr}
\hline & \multicolumn{2}{c}{2015} & & 2016 \\
\cline { 2 - 5 } & \multicolumn{2}{c}{ F1 } & F2 & F1 \\
\hline To have German ancestors & 0.90 & -0.02 & 0.93 & -0.05 \\
To be born in Germany & 0.88 & 0.01 & 0.90 & -0.01 \\
To have lived most of one's life in Germany & 0.83 & -0.03 & 0.84 & 0.02 \\
To have Christian worldview & 0.47 & 0.17 & 0.35 & 0.23 \\
To speak accent-free German & 0.67 & 0.12 & 0.64 & 0.12 \\
To share German manners and norms & 0.57 & 0.49 & 0.70 & 0.29 \\
To have democratic convictions & -0.02 & 0.77 & -0.01 & 0.82 \\
To attend one's civic duties & 0.23 & 0.75 & 0.14 & 0.86 \\
To treat all society's groups equally & -0.22 & 0.54 & -0.24 & 0.10 \\
correlation F1 with F2 & 0.01 & & 0.62 \\
\hline
\end{tabular}

Note: for 2015: $\mathrm{N}=2,426$; model fit: Chi2 $(\mathrm{df}=19)=149$, RMSEA $=0.053(\mathrm{Cl} 90$ per cent $[0.045,0.061]), \mathrm{CFI}=0.994$. For 2016: $\mathrm{N}=15,251 ;$ model fit: Chi2 $(\mathrm{df}=19)=1,437$, RMSEA $=0.070(\mathrm{Cl} 90$ per cent $[0.067,0.073]), \mathrm{CFI}=0.992$.

from these conceptions. People may feel torn and find it difficult to determine their position on related policy issues, in turn making their responses more variable, less stable and more difficult to predict. Following the approach proposed by Alvarez and Brehm (1995) we attempt to capture such variability by estimating not only each respondent's probability of agreeing with the statements concerning refugees and immigration, but also the amount of variance associated with the respondent's policy opinion.

To capture response variability we use ordered-logistic heteroscedastic regression models and model the variance in the responses to the immigration items. ${ }^{11}$ The idea underlying the modelling strategy is that if we could resample the same individuals and ask them the same question again, certain individuals would be more likely to give an alternative response; their range of plausible answers to the survey question is larger (Albertson, Brehm and Alvarez 2005). Since we cannot observe the same individual in several counterfactual states, we draw inferences about a single respondent's plausible range of responses based upon the observed responses of individuals sharing similar characteristics - the most important of which is their conception of national identity. A heterogeneous choice model allows us to model heteroscedasticity by simultaneously estimating two equations: one for the determinant of the choice, and another for the determinants of the residual variance. In short, we model the predicted error variance associated with each individual's response as a function of their conceptions of national identity (see Williams (2010) for a detailed description of the modelling strategy).

As a robustness test, we use the panel set-up of the GLES survey and study changes in immigration attitudes within the same individual over time, operationalizing response variability as the variance of a respondent's responses to the immigration item across waves of the study. Studying changes over time allows us to study the within-individual variation in which we are interested more directly. Yet studying changes over time does not allow us to ascertain whether variability corresponds to instability due to internal conflict, or instability due to changes in

\footnotetext{
${ }^{11}$ Heteroscedastic choice models have been used to study, e.g., political obfuscation (Franklin 1991), opinion formation and ambivalence (Alvarez and Brehm 1995; Alvarez and Brehm 2002) and stability of partisanship (Keele and Wolak 2006). They have been subject to some criticism, however, because they are sensitive to model specification and measurement error (Keele and Park 2006). These criticisms mainly apply to the binary heteroscedastic choice model, though: the ordinal heteroscedastic choice model, with its multiple responses, is less likely to suffer from these issues (Keele and Park 2006; Williams 2010). The ordinal model also does not confound the variance of the attitude with its degree of moderation (Mulligan 2013). Nevertheless, Keele and Park (2006) recommend carefully specifying the choice model (even if it is not of primary interest), using scales instead of categories, and engaging in extensive sensitivity testing. We take these cautionary notes seriously and carry out several robustness tests. For instance, we also operationalize 'response variability' in an alternative way, exploiting variability in individual opinions across waves of the GLES panel survey.
} 
Table 2. Weighted distribution of national identity types in 2015 and 2016

\begin{tabular}{lcccc}
\hline & \multicolumn{2}{c}{ Ethno-Cultural High } & \multicolumn{2}{c}{ Ethno-Cultural Low } \\
\cline { 2 - 3 } & 2015 & 2016 & 2015 & 2016 \\
\cline { 2 - 4 } Civic High & $36 \%$ & $42 \%$ & $36 \%$ & $34 \%$ \\
Civic Low & $17 \%$ & $10 \%$ & $11 \%$ & $15 \%$ \\
\hline
\end{tabular}

Note: figures based on dichotomized factor scores from the ESEM reported above; cut-off points are the scale midpoints.

external stimuli (malleability). If the composition of arguments in public discourse changed between time points, intra-individual variability could be an indicator of sensitivity to the framing of the issue in public discourse. ${ }^{12}$ In either case, we expect individuals who have an understanding of national identity that more closely resembles a theoretical ideal type (ethnocultural or civic) to have more crystallized and stable opinions or, put differently, to show less variation in their responses than individuals with mixed conceptions.

\section{Capturing Malleability}

Another implication of holding mixed conceptions of national identity is that attitudes among such individuals may be more malleable. Endorsing competing considerations about immigration may lead them to sway back and forth in their opinions depending on which considerations are made salient in the public debate. In order to study whether individuals with mixed conceptions have more malleable opinions, we exploit the experimental variation in the question wording of our dependent variable. The wording of the item 'Germany should make more efforts to help refugees in distress at sea [even if more refugees would then come to Germany]' includes an experimental variation that allows us to explore how sensitive respondents are to framing attempts - how malleable their attitudes toward the issue are. The short version of the item does not include a particular frame of reference. Helping refugees is a genuinely humanitarian issue, of course, so it is likely that citizens draw on related predispositions, including civic in-group norms, when evaluating the item. The long version asks about the same policy issue - thus also referencing humanitarian concerns - but additionally connects it with the welfare of the ingroup. The prospect of an increased inflow of refugees constitutes a symbolic threat for those who define the national in-group in ethno-cultural terms and should induce corresponding thoughts. The full sentence is thus likely to make additional (ethno-cultural) considerations salient. ${ }^{13}$ While we do not expect attitudes of individuals with ideal-type conceptions of national identity to be swayed by these considerations, we do expect this to be the case among individuals with mixed conceptions.

\section{Main Results}

This section begins by exploring the 2015 YouGov data and assessing the association between national identities and opinions about immigration. We continue by evaluating the effect of conflicting national identity conceptions on response variability. We then replicate our findings with 2016 GLES data and make use of the panel structure of this data source in order to operationalize response variability in an alternative way. Finally, we go back to the 2015 data and use the survey experiment to analyse whether individuals with mixed conceptions have more malleable opinions.

\footnotetext{
${ }^{12}$ The major shift in public discourse occurred before these data were collected. We therefore believe instability due to internal conflict is the more likely cause.

${ }^{13}$ This is not a strong treatment. However, we designed the experiment to match public discourse of the time and believe the results should correspond to realistic dynamics of public debate and actual elite framing (Haller 2017; Holmes and Castañeda 2016; Mushaben 2017; Trauner and Turton 2017).
} 
Table 3. Results from 2015 YouGov data

\begin{tabular}{|c|c|c|c|c|}
\hline & \multicolumn{4}{|c|}{$\begin{array}{l}\text { Dependent variable: Should Germany make efforts to help refugees at sea (even if } \\
\text { more refugees come to Germany)? }\end{array}$} \\
\hline & (1) & $(2)$ & (3) & (4) \\
\hline & Ordinal model & Variance model & Variance model & Variance model \\
\hline \multicolumn{5}{|l|}{ Variance model } \\
\hline Civic conception & - & $\begin{array}{l}-0.83^{*} \\
(0.41)\end{array}$ & $\begin{array}{l}-1.35^{\star} \\
(0.54)\end{array}$ & - \\
\hline Ethno-cultural conception & - & $\begin{array}{l}-1.91^{* * *} \\
(0.52)\end{array}$ & $\begin{array}{l}-2.82^{\star \star \star} \\
(0.72)\end{array}$ & - \\
\hline $\begin{array}{l}\text { Civic x Ethno-cultural } \\
\text { [Reference: Ideal-type Conceptions] }\end{array}$ & - & $\begin{array}{l}2.88^{\star \star \star} \\
(0.75)\end{array}$ & $\begin{array}{l}3.71^{\star \star \star} \\
(1.03)\end{array}$ & - \\
\hline Mixed Conceptions (nominal) & - & - & - & $\begin{array}{l}0.20^{\star \star} \\
(0.06)\end{array}$ \\
\hline No Conception (nominal) & - & - & - & $\begin{array}{c}0.07 \\
(0.06)\end{array}$ \\
\hline Attachment to nation & - & $\begin{array}{l}-0.04 \\
(0.03)\end{array}$ & $\begin{array}{c}0.05 \\
(0.04)\end{array}$ & $\begin{array}{l}-0.02 \\
(0.03)\end{array}$ \\
\hline Political interest & - & $\begin{array}{c}0.23^{\star} \\
(0.10)\end{array}$ & $\begin{array}{c}0.30^{\star} \\
(0.14)\end{array}$ & $\begin{array}{l}0.38^{\star \star \star} \\
(0.10)\end{array}$ \\
\hline Experimental Treatment & - & $\begin{array}{c}0.02 \\
(0.05)\end{array}$ & $\begin{array}{c}0.06 \\
(0.06)\end{array}$ & $\begin{array}{c}0.04 \\
(0.05)\end{array}$ \\
\hline Traditionalist & - & - & $\begin{array}{l}-0.27 \\
(0.45)\end{array}$ & - \\
\hline Universal & - & - & $\begin{array}{l}-0.49 \\
(0.37)\end{array}$ & - \\
\hline Traditionalist $\mathrm{x}$ Universal & - & - & $\begin{array}{c}0.67 \\
(0.62)\end{array}$ & - \\
\hline Ideological moderation & - & - & $\begin{array}{l}0.64^{\star \star} \\
(0.21)\end{array}$ & - \\
\hline Strength of PID & - & - & $\begin{array}{c}0.03 \\
(0.04)\end{array}$ & - \\
\hline Additional controls & - & No & Yes & Yes \\
\hline Choice model & & & & \\
\hline Civic conception & $\begin{array}{l}-0.97^{\star * *} \\
(0.26)\end{array}$ & $\begin{array}{l}-0.55^{*} \\
(0.23)\end{array}$ & $\begin{array}{l}-0.42 \\
(0.23)\end{array}$ & $\begin{array}{l}-1.07^{\star \star} \\
(0.35)\end{array}$ \\
\hline Ethno-cultural conception & $\begin{array}{l}2.87^{\star \star \star} \\
(0.28)\end{array}$ & $\begin{array}{l}1.72^{\star \star \star} \\
(0.50)\end{array}$ & $\begin{array}{l}1.16^{\star} \\
(0.54)\end{array}$ & $\begin{array}{l}3.47^{\star \star \star} \\
(0.61)\end{array}$ \\
\hline Attachment to the nation & $\begin{array}{l}0.16^{\star \star} \\
(0.06)\end{array}$ & $\begin{array}{c}0.09^{\star} \\
(0.04)\end{array}$ & $\begin{array}{c}0.04 \\
(0.03)\end{array}$ & $\begin{array}{c}0.17^{\star} \\
(0.07)\end{array}$ \\
\hline Political interest & $\begin{array}{l}-0.62^{\star * \star} \\
(0.06)\end{array}$ & $\begin{array}{l}-0.30^{*} \\
(0.15)\end{array}$ & $\begin{array}{l}-0.18 \\
(0.13)\end{array}$ & $\begin{array}{l}-0.78^{\star \star} \\
(0.27)\end{array}$ \\
\hline Experimental treatment & $\begin{array}{l}0.24^{\star \star} \\
(0.08)\end{array}$ & $\begin{array}{c}0.13^{*} \\
(0.06)\end{array}$ & $\begin{array}{c}0.07 \\
(0.05)\end{array}$ & $\begin{array}{l}0.28^{\star \star} \\
(0.10)\end{array}$ \\
\hline Additional controls & Yes & Yes & Yes & Yes \\
\hline $\mathrm{N}$ & 2,178 & 2,178 & 1,538 & 2,178 \\
\hline Likelihood ratio test $\left(\chi^{2}\right)$ & - & $49.32^{\star \star \star}$ & $73.19^{\star \star \star}$ & $53.27^{\star \star \star}$ \\
\hline AIC & 6,327 & 6,291 & 4,432 & 6,306 \\
\hline
\end{tabular}

Note: table reports coefficients from ordered-logistic regressions and ordered-logistic heteroscedastic models with standard errors in parentheses. Additional controls in variance and choice models (party identification, education, age, gender, place of residence) and cut-off points of the choice model not shown. ${ }^{\star} \mathrm{p}<0.05,{ }^{\star \star} \mathrm{p}<0.01,{ }^{\star \star \star} \mathrm{p}<0.001$

\section{Should Germany Aid Refugees?}

We analyse the association between conceptions of national identity and opinions on whether Germany should aid refugees. We begin by estimating an ordinal logistic regression without modelling the variance. The results are presented in Model 1 of Table 3. To control for potential 
confounding factors, we include variables capturing attachment to the nation, party identification and socio-demographic characteristics. Feeling attached to a group is sometimes sufficient for shaping out-group hostility irrespective of in-group norms. Party identity may influence not only solidarity with refugees via elite cueing but also partisans' conceptions of the nation. ${ }^{14} \mathrm{We}$ include socio-demographics as proxy variables for any additional omitted variables. These factors were measured with standard items, which are reported in the appendix.

As expected, having an ethno-cultural conception of nationhood reduces the willingness to aid refugees; people are more likely to disagree with the statement that Germany should make more efforts to save refugees at sea. Having a civic conception of nationhood, however, has a positive effect. Since the coefficients tell us little about the substantive magnitude of the estimated effects, we calculate predicted probabilities. Figure 1 illustrates the predicted probabilities of respondents falling into the different response categories, over a range of ethno-cultural and civic identity scores, holding all other variables constant at their mean value. As can be seen, having an ethnocultural conception of the nation increases the probability of disagreeing with the statement about Germany making more efforts to help refugees in distress at sea and having a civic conception decreases this probability. For example, all else constant, the probability of disagreeing somewhat with the statement (that is, to choose response category 4) is 5 (95 per cent $\mathrm{CI}=[2,9])$ per cent among individuals with a low ethno-cultural conception, and $18[9,23]$ per cent among those with a high ethno-cultural conception. ${ }^{15}$ The first difference is $13[4,19]$ percentage points. Having a civic understanding of national identity has the opposite effect: the probability of agreeing with the statement (to choose response category 1 ) is 12 [10,15] per cent among those with a low civic conception, and $23[20,26]$ per cent among those with a high civic conception. The first difference is $11[5,16]$ percentage points.

\section{Are Attitudes More Variable?}

We continue by estimating the heteroscedastic choice model in order to assess whether response variability is higher among individuals with mixed conceptions according to Hypothesis $2 .{ }^{16}$ To explain the error variance, we include the two variables capturing citizens' conception of the nation as well as their interaction. As discussed above, due to ambivalence, we expect the response variance to increase among citizens who conceptualize the nation both in terms of ethno-cultural and civic norms with respect to citizens with ideal-type conceptions. The coefficients can be found under the remaining models in Table 3. The coefficients of the choice model (and their standard errors) represent the estimated effects within a group where all the coefficients of the variance equation have a predicted standard deviation of the residual error of zero (when $\sigma=1$ ). ${ }^{17}$ As can be seen, the results from the choice model remain similar, but drop somewhat in effect size.

The coefficients in the variance model indicate the direction and statistical significance of our estimates on the error variance. As can be seen, the effect of the civic (ethno-cultural) conception is positive when the value of the ethno-cultural (civic) conception is high, indicating an increase in variability among individuals with mixed conceptions compared to those with ideal-type conceptions.

\footnotetext{
${ }^{14} \mathrm{By}$ controlling for party identity, we employ a conservative strategy because citizens may identify with a party because its conception of the nation matches their own. Thus national identity may have an indirect effect on solidarity via party identity, which we parcel out by controlling for the latter.

${ }^{15}$ By taking 1,000 random draws from a multivariate normal distribution with means corresponding to the coefficients, and variance corresponding to the variance-covariance matrix, we estimate simulated 95 per cent confidence intervals for our predictions (presented in brackets). In our calculations we chose 0.1 and 0.9 as 'high' and 'low' values on the ethnocultural and civic conception variables (which range from 0 to 1.).

${ }^{16}$ We estimate the model using the R package 'olgmx' (Carroll 2016).

${ }^{17}$ The reported coefficients and corresponding p-values in the choice equation must therefore be interpreted with caution. $\mathrm{P}$-values indicate whether or not the effect differs from zero for a group that has a value of zero for all other variables in the variance equation (Williams 2010).
} 


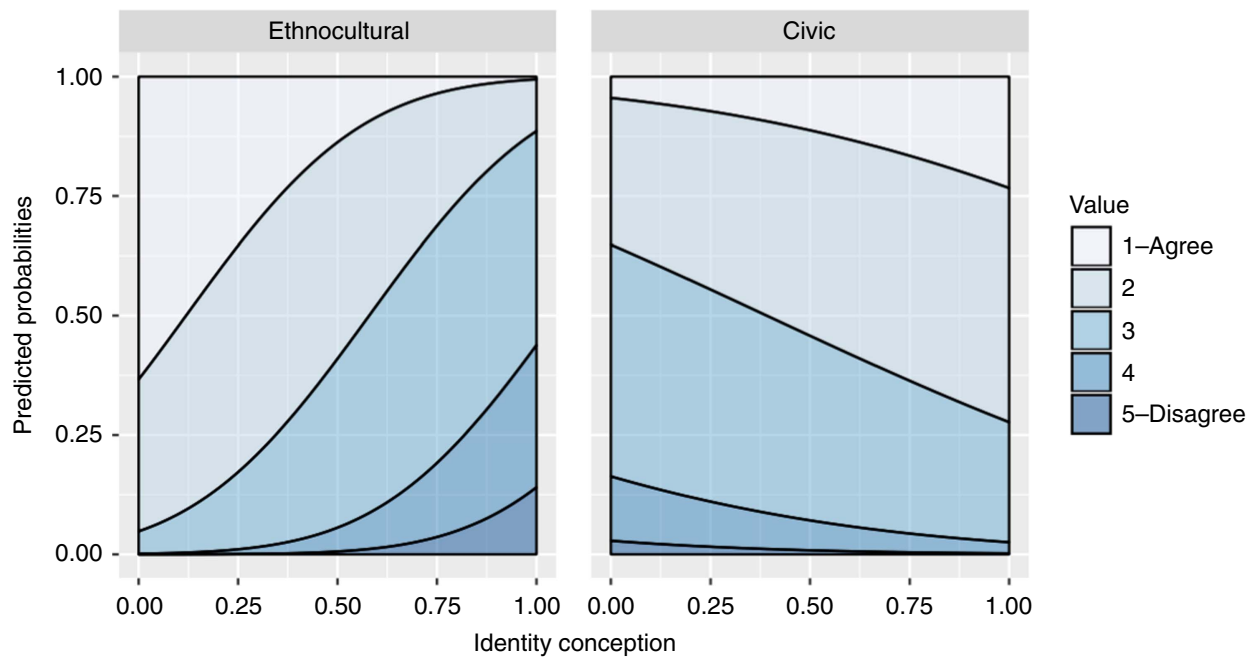

Figure 1. Effect of national identity conception on support for helping refugees (1-5)

Note: predicted probabilities of respondents being in different response categories given different levels of ethno-cultural and civic identity. The predictions are based on Model 1 in Table 3.

Source: 2015 YouGov data

In order to assess the substantive effects of our estimates, we predict the estimated error variance over a range of our independent variables of interest. The predicted standard deviation of the residual error $(\sigma)$ is $0.22[0.09,0.51]$ for individuals with high values on the ethno-cultural dimension and low values on the civic dimension, while it is $0.52[0.26,1.03]$ for individuals who conceptualize the nation exclusively in civic terms. In line with our argument, $\sigma$ is 0.90 [0.54, 1.48] for individuals who believe both ethno-cultural and civic criteria are important, and thus higher than in the other two cases. The first differences between the predicted values are statistically different from zero. ${ }^{18}$ Figure 2 plots the predicted standard deviation of the residuals across different values of ethno-cultural and civic conceptions. It shows that response variability increases among respondents with mixed conceptions. We also estimate the model using nominal measures of national configurations distinguishing between respondents with mixed conceptions, ideal-type conceptions and no clear conception. The cut-off points are below and above the median value. The results are presented in Model 4 and point towards the same pattern: individuals with mixed conceptions of the nation exhibit higher response variability than those with ideal-type conceptions. ${ }^{19}$

To test whether the variance component increases the fit of the model from a statistical point of view, we carried out log-likelihood ratio tests of the heteroscedastic models against the analogous models without the variance component (Alvarez and Brehm 1995; Keele and Wolak 2006; Rudolph 2005). By modelling the heteroscedasticity we find significant improvements in model fit (see Table 3). We thus reject the null hypothesis of homoscedasticity.

\footnotetext{
${ }^{18}$ The estimates are calculated using the coefficients from Model 2, Table 3. Again, we chose 0.1 and 0.9 as 'high' and 'low' values on the ethno-cultural and civic conception variables.

${ }^{19}$ As we have seen, simultaneously believing both ethno-cultural and civic criteria matter for national identity increases response variability, with respect to those who have a more ideal-typical conception of the nation. However, internal conflict is not the only cause of response variability. As Alvarez and Brehm (2002) and Craig, Martinez and Kane (2005) point out, response variability may also be the result of uncertainty or indifference. Unlike uncertainty or indifference, response variability is unlikely to decrease among ambivalent individuals as a result of increased information relevant to the issue (Alvarez and Brehm 2002). We therefore study differences in effect sizes for politically interested and non-interested individuals, and find that among individuals with mixed conceptions, error variance increases among the politically interested. See Appendix Table A7 and Figure A2 for the results.
} 


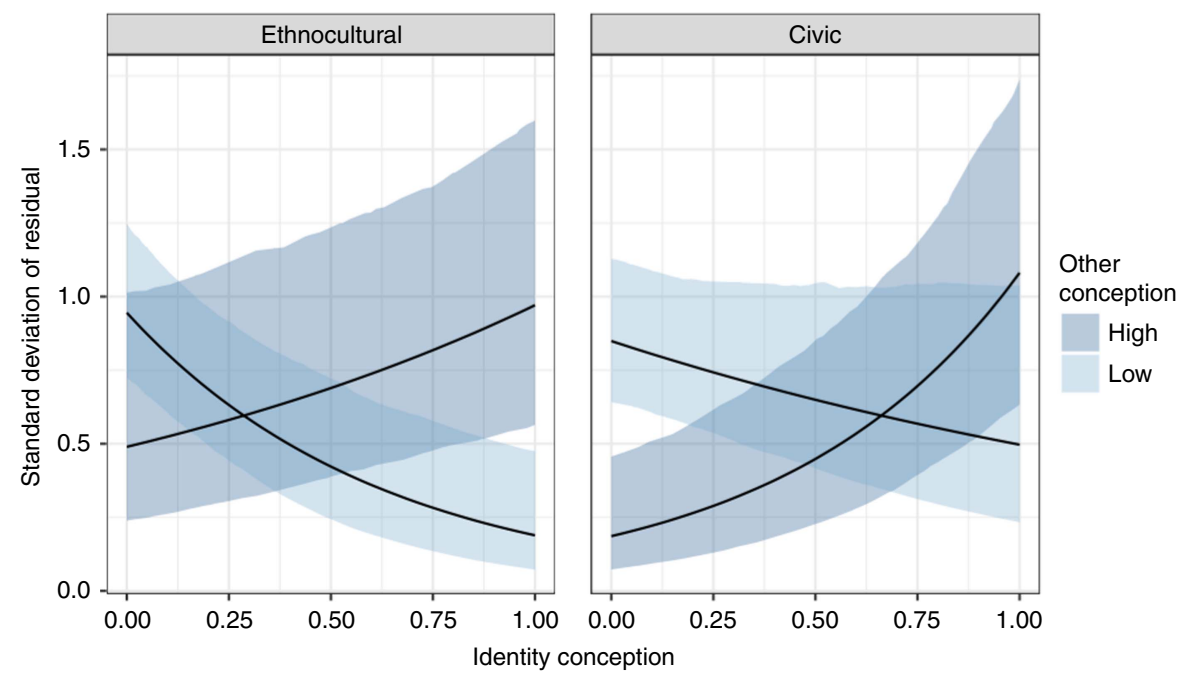

Figure 2. Effect of national identity conception on response variability

Note: predicted standard deviation of the residual error across a range of values of the ethno-cultural conceptions for high and low values of the civic conception (left panel) and a range of values of the civic conceptions for high and low values of the ethno-cultural conception (right panel) based on coefficients from Table 3, Model 2. Shaded areas are simulated 95 per cent confidence intervals. Source: 2015 YouGov data

We control for additional variables in the variance equation, including party identification, strength of party identification and ideological moderation (see Model 3). In order to gain confidence that these effects are driven by considerations based on civic and ethno-cultural conceptions of national identity and not (merely) by considerations based on values, we also control for the interaction between universalistic and traditionalist values. The results remain robust. ${ }^{20}$

\section{Should Immigration Be Facilitated or Restricted?}

Next, we replicate our findings using data from the GLES. Replicating our findings with another data source helps ease concerns about model sensitivity that are sometimes raised about heteroscedastic choice models (Keele and Park 2006). Moreover, given the panel structure of this data source, we attempt to capture 'response variability' in an alternative way.

The results do replicate with this dataset. While individuals who have an ethno-cultural conception are more likely to believe immigration should be restricted, those with a civic conception are more likely to claim that it should be facilitated (see Model 1, Table 4). As can be seen in Figure 3 and Models 2 and 3 of Table 4, the results on response variability also hold. The effect of having an ethno-cultural (civic) conception of the nation on response variability is negative among individuals who do not believe civic (ethno-cultural) criteria matter for national membership. In contrast, it has a positive effect on response variability among individuals who believe the alternative criteria matter as well. The predicted standard deviation of the residual is $0.36[0.26,0.50]$ for individuals with a high ethno-cultural conception, $0.54[0.43,0.69]$ for those with a high civic conception and $0.69[0.58,0.82]$ for those with mixed conceptions. The first differences are statistically different from zero.

In addition to modelling the conditional response variance, we use the GLES panel data structure and operationalize 'response variability' in a different way. Rather than model heteroscedasticity, we study the likelihood that the same individual varies his or her opinion across waves. Our expectation is that respondents who believe that both ethno-cultural and civic criteria are important for national membership should be more likely to change back and forth in their

\footnotetext{
${ }^{20}$ The justification for including these particular values and additional controls is presented in the appendix.
} 
Table 4. Results from GLES data

Dependent variable: Should immigration be facilitated or restricted?

\begin{tabular}{|c|c|c|c|}
\hline (1) & $(2)$ & (3) & (4) \\
\hline Choice model (w1) & Variance model (w1) & Variance model (w1) & Panel (w1-w4, w6-w8) \\
\hline Ordered logistic & Heteroscedastic & Heteroscedastic & OLS \\
\hline
\end{tabular}

\begin{tabular}{|c|c|c|c|c|}
\hline \multicolumn{5}{|l|}{ Variance model } \\
\hline Civic conception & - & $\begin{array}{l}-0.73^{\star \star \star} \\
(0.14)\end{array}$ & $\begin{array}{l}-0.68^{\star \star \star} \\
(0.15)\end{array}$ & - \\
\hline Ethno-cultural conception & - & $\begin{array}{l}-1.25^{\star \star \star} \\
(0.21)\end{array}$ & $\begin{array}{l}-1.03^{\star \star \star} \\
(0.21)\end{array}$ & - \\
\hline Civic $x$ Ethno-cultural & - & $\begin{array}{l}1.72^{\star \star \star} \\
(0.30)\end{array}$ & $\begin{array}{l}1.45^{\star \star \star} \\
(0.30)\end{array}$ & - \\
\hline Attachment to nation & - & $\begin{array}{c}-0.03^{*} \\
(0.01)\end{array}$ & $\begin{array}{c}-0.03^{*} \\
(0.01)\end{array}$ & - \\
\hline Political interest & - & $\begin{array}{c}0.03^{*} \\
(0.01)\end{array}$ & $\begin{array}{c}0.03^{*} \\
(0.01)\end{array}$ & - \\
\hline Strength of PID & - & $\begin{array}{c}0.01^{*} \\
(0.01)\end{array}$ & $\begin{array}{c}0.01^{*} \\
(0.01)\end{array}$ & - \\
\hline Traditionalist & - & - & $\begin{array}{l}-1.20^{\star \star \star} \\
(0.17)\end{array}$ & - \\
\hline Universal & - & - & $\begin{array}{l}-0.43^{\star \star *} \\
(0.12)\end{array}$ & - \\
\hline Conc Traditionalist $\mathrm{x}$ Universal & - & - & $\begin{array}{l}1.49^{\star \star \star} \\
(0.22)\end{array}$ & - \\
\hline Additional controls & - & No & Yes & - \\
\hline Choice model & & & & \\
\hline Civic conception & $\begin{array}{l}-0.88^{\star \star \star} \\
(0.12)\end{array}$ & $\begin{array}{l}-0.45^{\star \star \star} \\
(0.08)\end{array}$ & $\begin{array}{l}-0.32^{\star \star \star} \\
(0.06)\end{array}$ & $\begin{array}{c}-1.17^{\star \star} \\
(0.39)\end{array}$ \\
\hline Ethno-cultural conception & $\begin{array}{l}3.15^{\star \star \star} \\
(0.13)\end{array}$ & $\begin{array}{l}1.84^{\star \star \star} \\
(0.19)\end{array}$ & $\begin{array}{l}1.33^{\star \star \star} \\
(0.16)\end{array}$ & $\begin{array}{c}-1.30^{\star} \\
(0.51)\end{array}$ \\
\hline Civic $x$ Ethno-cultural & - & - & - & $\begin{array}{c}1.52^{\star} \\
(0.71)\end{array}$ \\
\hline Additional controls & Yes & Yes & Yes & Yes \\
\hline $\mathrm{N}$ & 14,378 & 14,378 & 14,378 & 5,163 \\
\hline Likelihood ratio test $\left(\chi^{2}\right)$ & - & $105.85^{\star \star \star}$ & $221.57^{\star \star \star}$ & - \\
\hline AIC & 46,235 & 46,142 & 46,031 & 4,076 \\
\hline
\end{tabular}

Note: table reports coefficients from ordered-logistic regressions and ordered-logistic heteroscedastic models with standard errors in parentheses. Additional controls (education, age, gender, attachment to the nation, place of residence) and cut-off points of the choice model not shown. ${ }^{\star} p<0.05,{ }^{\star \star} p<0.01,{ }^{\star \star *} p<0.001$

opinions than individuals who have more ideal-typical conceptions. ${ }^{21}$ To capture response variability we calculate the variance of the response to the immigration item for each individual across seven waves of the GLES panel. ${ }^{22}$ Individuals who do not change their opinions about immigration thus receive a value of 0 , while those whose opinions vary a lot receive higher scores. The results, presented in Model 4 of Table 4, point towards the same pattern. Appendix Figure A3 shows that individuals with mixed conceptions exhibit higher variability than those with ideal-type conceptions, although these differences are not consistently statistically significant at conventional levels.

To sum up, our previous finding replicates with a different data set, suggesting that the results are robust. Furthermore, we find a similar trend when operationalizing response variability as changing opinion over time, further increasing confidence in our findings.

\footnotetext{
${ }^{21}$ Keele and Wolak (2006) used a similar approach to assess ambivalence and partisan stability.

${ }^{22}$ Nine waves are currently available. Waves 5 and 9 are excluded from the analysis, however, as the question was not posed in those waves.
} 


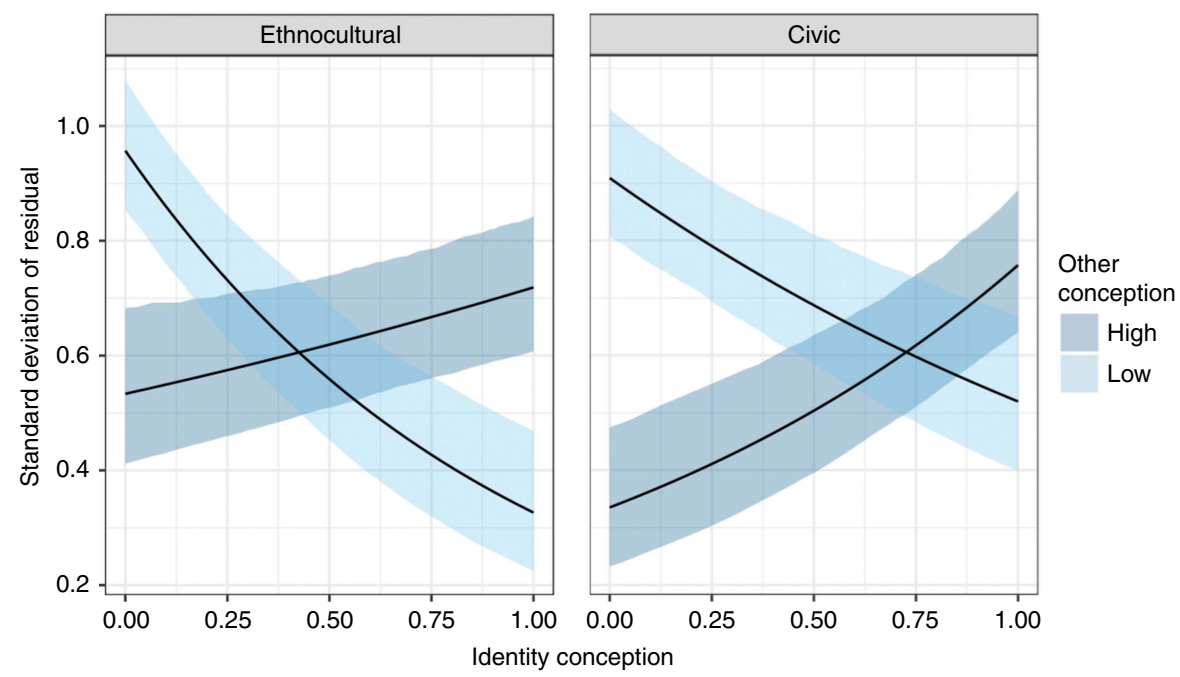

Figure 3. Effect of national identity conception on response variability

Note: predicted standard deviation of the residual error across a range of values of the ethno-cultural conceptions for high and low values of the civic conception (left panel) and a range of values of the civic conceptions for high and low values of the ethno-cultural conception (right panel) based on coefficients from Table 4, Model 2. Shaded areas are simulated 95 per cent confidence intervals. Source: 2016 GLES data

\section{Are Attitudes more Malleable?}

We have found that holding mixed conceptions of national identity increases response variability among respondents. In a next step, we explore whether attitudes are also more malleable among such respondents as predicted in Hypothesis 3. In order to do so, we again draw from the 2015 online survey and study the experimental variation in the wording of our dependent variable in order to explore sensitivity to framing. Half of the respondents receive the item including the full sentence: 'Germany should make more efforts to help refugees in distress at sea [even if more refugees would then come to Germany]' (treatment group), and the other half receive the short version (the control group). The experimental variation is designed to increase the salience of an additional consideration. While the short version is likely to elicit considerations regarding humanitarianism, the full sentence is also likely to elicit considerations regarding the national ingroup. We expect the salience of the additional consideration to be more likely to sway opinions among individuals with mixed conceptions of national identity. Since such individuals are likely to endorse both types of considerations, the salience of one type of consideration or other is likely to pull the respondent in different directions.

In order to assess whether individuals with mixed conceptions are more sensitive to framing, we study heterogeneous treatment effects across groups of respondents. For simplicity, we use the nominal measures of national identity configurations, distinguishing between respondents with mixed conceptions, mainly ethno-cultural conceptions, mainly civic conceptions and no clear conceptions. The cut-off points are below and above the median value. Model 1 of Table 5 demonstrates that the average treatment effect across groups is positive and just short of statistical significance. Individuals exposed to the full sentence are somewhat more likely to oppose that Germany should help refugees. The substantive effect, however, is quite small. As shown in the remaining models, there is considerable heterogeneity across groups. In line with our expectations, individuals with mixed conceptions appear to be most sensitive to the question wording. As shown in Model 3, the treatment increases opposition to helping refugees by 0.35 points on a 1-5 scale among individuals with mixed conceptions. Figure 4 plots the treatment effect among respondents with mixed conceptions and those with one-sided (ideal-type) 


\begin{tabular}{|c|c|c|c|c|c|c|}
\hline & \multicolumn{6}{|c|}{$\begin{array}{l}\text { Dependent variable: Should Germany make efforts to help refugees at sea (even if } \\
\text { more refugees come to Germany)? }\end{array}$} \\
\hline & (1) & $(2)$ & (3) & (4) & (5) & (6) \\
\hline & (OLS) & (OLS) & (OLS) & $\begin{array}{l}\text { (Ordered } \\
\text { logistic) }\end{array}$ & $\begin{array}{l}\text { (Ordered } \\
\text { logistic) }\end{array}$ & $\begin{array}{l}\text { (Ordered } \\
\text { logistic) }\end{array}$ \\
\hline & & $\begin{array}{l}\text { (ref: one- } \\
\text { sided) }\end{array}$ & $\begin{array}{l}\text { (ref: one- } \\
\text { sided) }\end{array}$ & $\begin{array}{l}\text { (ref: one- } \\
\text { sided) }\end{array}$ & $\begin{array}{l}\text { (ref: ethno- } \\
\text { cultural) }\end{array}$ & (ref: civic) \\
\hline Treatment & $\begin{array}{c}0.11 \\
(0.06)\end{array}$ & $\begin{array}{c}0.03 \\
(0.08)\end{array}$ & $\begin{array}{c}0.02 \\
(0.07)\end{array}$ & $\begin{array}{c}0.04 \\
(0.10)\end{array}$ & $\begin{array}{c}0.10 \\
(0.13)\end{array}$ & $\begin{array}{c}0.08 \\
(0.16)\end{array}$ \\
\hline Treatment $\mathrm{x}$ Mixed conceptions & - & $\begin{array}{c}0.25 \\
(0.14)\end{array}$ & $\begin{array}{c}0.33^{\star} \\
(0.13)\end{array}$ & $\begin{array}{c}0.52^{\star} \\
(0.20)\end{array}$ & $\begin{array}{c}0.46^{\star} \\
(0.22)\end{array}$ & $\begin{array}{c}0.48^{\star} \\
(0.24)\end{array}$ \\
\hline Treatment $\mathrm{x}$ No conception & - & $\begin{array}{c}0.14 \\
(0.14)\end{array}$ & $\begin{array}{c}0.21 \\
(0.13)\end{array}$ & $\begin{array}{c}0.22 \\
(0.20)\end{array}$ & $\begin{array}{c}0.15 \\
(0.22)\end{array}$ & $\begin{array}{c}0.18 \\
(0.24)\end{array}$ \\
\hline Treatment $x$ Ethno-cultural & - & - & - & - & - & $\begin{array}{c}0.03 \\
(0.21)\end{array}$ \\
\hline Treatment x Civic & - & - & - & - & $\begin{array}{c}-0.03 \\
(0.21)\end{array}$ & - \\
\hline Mixed conceptions & - & $\begin{array}{c}0.05 \\
(0.23)\end{array}$ & $\begin{array}{c}-0.29 \\
(0.21)\end{array}$ & $\begin{array}{c}-0.48 \\
(0.32)\end{array}$ & $\begin{array}{c}-0.77^{\star} \\
(0.35)\end{array}$ & $\begin{array}{c}0.05 \\
(0.38)\end{array}$ \\
\hline No conception & - & $\begin{array}{c}-0.42 \\
(0.21)\end{array}$ & $\begin{array}{c}-0.43^{\star} \\
(0.20)\end{array}$ & $\begin{array}{c}-0.49 \\
(0.31)\end{array}$ & $\begin{array}{c}-0.83^{*} \\
(0.34)\end{array}$ & $\begin{array}{c}-0.02 \\
(0.37)\end{array}$ \\
\hline Ethno-cultural & - & - & - & - & - & $\begin{array}{c}0.82^{\star} \\
(0.33)\end{array}$ \\
\hline Civic & - & - & - & - & $\begin{array}{c}-0.82^{\star} \\
(0.33)\end{array}$ & - \\
\hline Additional controls & No & No & Yes & Yes & Yes & Yes \\
\hline $\mathrm{N}$ & 2,178 & 2,178 & 2,178 & 2,178 & 2,178 & 2,178 \\
\hline AIC & 3,781 & 3,676 & 3,194 & 6,462 & 6,406 & 6,406 \\
\hline
\end{tabular}

Note: table reports unstandardized coefficients with standard errors in parentheses. Additional controls (party identification, education, age, gender, place of residence, attachment to the nation, political interest) and cut-off points of the ordinal models not shown. ${ }^{*} \mathrm{p}<0.05$, ${ }^{\star \star} \mathrm{p}<0.01,{ }^{\star \star \star} \mathrm{p}<0.001$

conceptions. While the treatment has no effect on individuals with ideal-type conceptions, it has a positive impact on individuals with mixed conceptions.

In summary, we find that while having a civic conception of national identity increases support for helping refugees, having an ethno-cultural conception has the opposite effect. We also find that response variability is higher among individuals with mixed conceptions than among those with ideal-type conceptions, suggesting that individuals with mixed conceptions may face greater difficulty in shaping an opinion. Finally, sensitivity to the framing of the refugee situation appears to be highest among respondents with mixed conceptions, suggesting that these individuals hold more malleable immigration attitudes.

\section{Conclusion}

We have explored how German citizens' conceptions of national identity affect opinion formation on immigration-related topics. Building on the idea that citizens may subscribe to two ideal-typical conceptions of the nation, we demonstrate that while some 'constellations' of national identities lend structure and stability to political opinions, others are more likely to give rise to ambivalence and - as a consequence - fickle and changing opinions.

As for the 'pure' types, having an ethno-cultural conception of the nation reduces solidarity with refugees and makes citizens more sceptical of immigration in general. Subscribing to a civic 


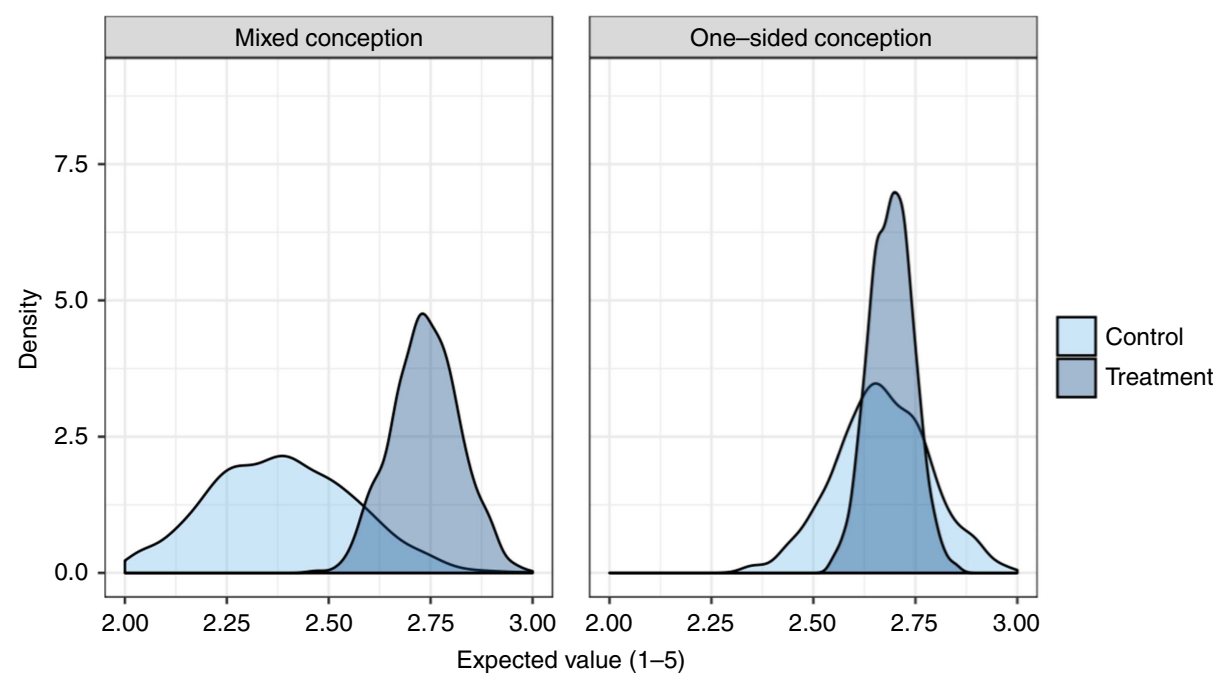

Figure 4. Effect of framing treatment on support for helping refugees

Note: expected attitude towards aiding refugees given experimental treatment for individuals with mixed conceptions and one-sided (idealtype) conceptions ( $1=$ agree, $5=$ disagree). Coefficients from Model 3 of Table 5 . Shaded areas are simulated confidence intervals.

Source: 2015 YouGov data

conception of nationhood, in contrast, leads to more solidarity with refugees and more openness to immigration. This latter finding is noteworthy because prior research has produced mixed findings regarding the civic dimension. While civic criteria of nationhood may be used as symbolic resources for exclusion - for example by denying Muslims the capacity to embrace democracy - their content implies solidarity and openness. Our results show that in a context in which the latter implications are a prominent frame in public discourse, the latter implication prevailed. At the methodological level we have employed items specifically designed to tap into the civic dimension, thereby avoiding a problem that has plagued many previous contributions on the differential effects of the ethno-cultural and civic conceptions of national identity (Wright, Citrin and Wand 2012).

The findings also indicate that significant portions of the German public subscribe to both ethno-cultural and civic conceptions of nationhood. We argue that these mixed conceptions of national identity may give rise to conflicting considerations regarding immigration. Building on the concept of ambivalence, we demonstrate that individuals with mixed conceptions have more variable opinions than those with more 'ideal-type' national identities. Thus the impact of national identities does not always lend structure and stability to political attitudes; it can also make people more hesitant, and their opinion more volatile. Future research should trace the psychological processes that generate this volatility in more detail, using more direct measures of felt conflict. Our results further suggest that individuals who hold mixed conceptions of national identity are more sensitive to the salience of additional considerations. Issues that touch upon conceptions of nationhood may therefore give political elites more leeway in policy making than is suggested by conventional wisdom. Elites may have the capacity to shape public opinion by highlighting or downplaying one or both conceptions of the nation.

In this article we study opinion formation in Germany. Focusing on a single case naturally raises the issue of generalizability, and contemporary German national identity is, in many respects, a special case due to the need to come to terms with its history of Nazism. However, the feature that makes it a most likely case for the ambivalence effects analysed in this article - the presence of two different and salient traditions of conceiving the nation - is not uncommon in other contexts. Most nations have multiple, rivalling narratives of the nation, and the increasing 
diversity in modern societies has raised the salience of issues touching on national identities in many countries. For example, in the United States both the civic and ethno-cultural perspectives have a long history (Lieven 2004; Smith 1988), and the constant influx of immigrants (especially from non-European countries) has made these conflicting conceptions of American national identity salient.

On a related note, identity-induced ambivalence is not necessarily restricted to the issue of immigration, but might extend to a range of other issues. National identities inform citizens' opinion formation not only on immigration but also on a host of other issues such as regional integration, international trade and cultural diversity. People subscribing to conflicting notions of nationhood may experience similar forms of ambivalence and show similar dynamics in opinion formation when responding to these issues. Yet, issues may differ in the likelihood of giving rise to debates between proponents of competing notions of nationhood. For example, issues such as immigration and cultural diversity provide straightforward cues (for example, people who look 'foreign'), pointing to the ethno-cultural conception of nationality. International trade, by contrast, does not provide such inevitable cues. The latter kind of issues may therefore be less likely to produce two-sided debates that in turn are conducive to destabilizing effects of subscribing to different notions of nationhood. Furthermore, competing conceptions of the in-group are not always confined to the nation. The meaning of European identity, for instance, is also contested, with proponents of civic and ethno-cultural ideas competing for influence. If our line of reasoning is correct, we should expect similar effects of simultaneously holding different notions of Europe on opinion formation.

The civic and ethno-cultural conceptions of national identity are not the only dispositions that may come into conflict when citizens think about immigration or related issues. For instance, the literature on value ambivalence would suggest that value orientations such as tradition and universalism might induce ambivalence. Our central point is to argue that conceptions of national identity may, at least under some circumstances, also induce ambivalence. Viewed from the ambivalence literature, our article therefore contributes by studying ambivalence in relation to a psychological phenomenon it has not been applied to before - conceptions of national identity. We believe that the ethnic/civic distinction is a particularly interesting framework to use, given that this distinction is so prominent in the literature. This is not to say, however, that the civic/ethnic framework is unique; ethno-cultural and civic national identities may be only one source of ambivalence. Conceptions of national membership may also come into conflict with other aspects of nationality. For instance, one might expect that ethno-culturally orientated citizens who are at the same time uncritically loyal to the nation may experience ambivalence if the national leaders enact policies that violate ethno-cultural norms.

With regard to future research, one implication of our argument is that individuals are more likely to experience ambivalence induced by competing national identities in societies where the boundaries and content of nationhood are under debate. Likewise, public discourse that highlights the simultaneous importance of competing notions of nationhood may give rise to the effects of ambivalence on opinion formation analysed in this article. By implication, changes in public discourse - having no identity content, either ethno-cultural or civic nationhood, or both ethno-cultural and civic nationhood - should moderate the impact of conflicting ideas on opinion formation at the individual level. Whether or not individual-level struggles in coming to terms with changing societies vary across contexts in this way is an important avenue for future comparative research.

To conclude, many citizens find it hard to form an opinion on how to deal with increased immigration. Issues concerning solidarity with outsiders touch on several values and norms that push those who embrace them in different directions. Ambivalent individuals tend to have volatile and changing opinions, which has several implications. Sudden swings in public opinion are likely to make it difficult for policy makers to design policies in line with public preferences. Furthermore, ambivalent attitudes are more likely to be unstable, persuadable and potentially susceptible to elite manipulation. It is therefore important to understand among which 
individuals, and even among which societies, ambivalence regarding immigration and other issues is more likely. We have argued and presented evidence that people whose national identity is defined by both ethno-cultural and civic criteria may experience such ambivalence. This insight adds an important qualification to the literature on the role of national identities for attitude formation on many issues in an era of permeable and contested borders.

Supplementary material. Data replication sets are available in Harvard Dataverse at: https://doi.org/10.7910/DVN/A48JP7 and online apendices at: https://doi.org/10.1017/S0007123418000522

\section{References}

Albertson B, Brehm J and Alvarez RM (2005) Ambivalence as internal conflict. In Craig SC and Martinez MD (eds), Ambivalence and the Structure of Political Opinion. New York: Palgrave Macmillan US, pp. 15-32.

Alvarez RM and Brehm J (1995) American ambivalence towards abortion policy: development of a heteroscedastic probit model of competing values. American Journal of Political Science 39 (4):1055-1082.

Alvarez RM and Brehm J (2002) Hard Choices, Easy Answers: Values, Information, and American Public Opinion. Princeton, NJ: Princeton University Press.

Ariely G (2011) Constitutional patriotism, liberal nationalism and membership in the nation: an empirical assessment. Acta Politica 46 (3):294-319.

Asparouhov T and Muthén B (2009) Exploratory structural equation modeling. Structural Equation Modeling: A Multidisciplinary Journal 16 (3):397-438.

Basinger SJ and Lavine H (2005) Ambivalence, information, and electoral choice. American Political Science Review 99 (2):169-184.

Becker E (2017) Good mosque, bad mosque: boundaries to belonging in contemporary Germany. Journal of the American Academy of Religion 85 (4):1050-1088.

BMI (2016) 890.000 Asylsuchende im Jahr 2015. Pressemitteilung des Bundesministerium des Innern (BMI), 30.09.2016. [890,000 asylum seekers in 2015. Press release of the Federal Ministry of the Interior.]

Bonikowski B and DiMaggio P (2016) Varieties of American popular nationalism. American Sociological Review 81 (5):949-980.

Branscombe NR et al. (1999) The context and content of social identity threat. In Ellemers N (ed.), Social Identity: Context, Commitment, Content. Oxford: Blackwell, pp. 35-58.

Brubaker R (1992) Citizenship and Nationhood in France and Germany. Cambridge, MA: Harvard University Press.

Carey S (2002) Undivided loyalties: is national identity an obstacle to European integration? European Union Politics 3 (4):387-413.

Carroll N (2016) oglmx: a package for estimation of ordered generalized linear models. Available at https://cran.r-project. org/web/packages/oglmx/index.html (accessed 27 November 2018).

Chouliaraki L et al. (2017) The European 'migration crisis' and the media: a cross-European press content analysis. London: London School of Economics and Political Science.

Citrin J, Reingold B and Green DP (1990) American identity and the politics of ethnic change. The Journal of Politics 52 (4):1124-1154.

Citrin J and Sears DO (2014) American Identity and the Politics of Multiculturalism. New York: Cambridge University Press.

Citrin J and Sides J (2008) Immigration and the imagined community in Europe and the United States. Political Studies 56 (1):33-56.

Citrin J and Wright M (2008) The collision of national identity and multiculturalism among mass publics. Paper prepared for the 2008 Annual Meeting of the Midwest Political Science Association, 4-7 April, Chicago, IL.

Clarke HD, Goodwin M and Whiteley P (2017) Brexit: Why Britain Voted to Leave the European Union. Cambridge: Cambridge University Press.

Craig SC, Martinez MD and Kane JG (2005) Core values, value conflict, and citizens' ambivalence about gay rights. Political Research Quarterly 58 (1):5-17.

Esses VM et al. (2006) Perceptions of national identity and attitudes toward immigrants and immigration in Canada and Germany. International Journal of Intercultural Relations 30 (6):653-669.

Franklin CH (1991) Eschewing obfuscation? Campaigns and the perception of US Senate incumbents. American Political Science Review 85 (4):1193-1214.

Green S (2013) Germany: a changing country of immigration. German Politics 22 (3):333-351.

Habermas J (1990) Die Nachholende Revolution [The Catch-up Revolution]. Frankfurt am Main: Suhrkamp.

Hainmueller J and Hopkins DJ (2015) The hidden American immigration consensus: a conjoint analysis of attitudes toward immigrants. American Journal of Political Science 59 (3):529-548.

Haller M (2017) Die 'Flüchtlingskrise' in den Medien. Tagesaktueller Journalismus zwischen Meinung und Information. [The 'refugee crisis' in the media. Daily journalism between opinion and information.] Frankfurt: Otto-Brenner-Stiftung. 
Hollinger DA (2006) Post-ethnic America: Beyond Multiculturalism. New York: Basic Books.

Holmes SM and Castañeda H (2016) Representing the 'European refugee crisis' in Germany and beyond: deservingness and difference, life and death. American Ethnologist 43 (1):12-24.

Hooghe L and Marks G (2005) Calculation, community and cues: public opinion on European integration. European Union Politics 6 (4):419-443.

Janmaat JG (2006) Popular conceptions of nationhood in old and new European member states: partial support for the ethnic-civic framework. Ethnic and Racial Studies 29 (1):50-78.

Jones FL and Smith P (2001) Diversity and commonality in national identities: an exploratory analysis of cross-national patterns. Journal of Sociology 37 (1):45-63.

Keele L and Park DK (2006) Difficult choices: an evaluation of heterogeneous choice models. Paper prepared for the 2004 Meeting of the American Political Science Association, 2-5 September 2004, Chicago, IL [revised version from 3 March 2006].

Keele L and Wolak J (2006) Value conflict and volatility in party identification. British Journal of Political Science 36 (4):671-690.

Kinnvall C and Nesbitt-Larking P (2011) The Political Psychology of Globalization: Muslims in the West. New York: Oxford University Press.

Kohn H (1944) The Idea of Nationalism: A Study in its Origins and Background. New York: Macmillan.

Kratz A and Schoen H (2017) Just like leaves in the wind? Exploring the effect of the interplay of media coverage and personal characteristics on issue salience. In Schoen $\mathrm{H}$ et al. (eds), Voters and Voting in Context: Multiple Contexts and the Heterogeneous German Electorate. Oxford: Oxford University Press, pp. 43-70.

Kronenberg V (2013) Patriotismus in Deutschland. Perspektiven für eine weltoffene Nation. 3rd edition. [Patriotism in Germany. Perspectives for a cosmopolitan nation.] Wiesbaden: Springer.

Kunovich RM (2009) The sources and consequences of national identification. American Sociological Review 74 (4):573-593.

Kurthen H (1995) Germany at the crossroads: national identity and the challenges of immigration. International Migration Review 29 (4):914-938.

Kuzio T (2002) The myth of the civic state: a critical survey of Hans Kohn's framework for understanding nationalism. Ethnic and Racial Studies 25 (1):20-39.

Larsen CA (2017) Revitalizing the 'civic' and 'ethnic' distinction. Perceptions of nationhood across two dimensions, 44 countries and two decades. Nations and Nationalism 23 (4):970-993.

Lavine H (2001) The electoral consequences of ambivalence toward presidential candidates. American Journal of Political Science 45 (4):915-929.

Lavine H (2004) Attitude ambivalence in the realm of politics. In Haddock G and Maio GR (eds), Contemporary Perspectives on the Psychology of Attitudes. New York: Psychology Press, pp. 111-138.

Lieven A (2004) America Right or Wrong: An Anatomy of American Nationalism. New York: Oxford University Press.

Mader M (2016) Stabilität und Wandel der nationalen Identität in der deutschen Bevölkerung. [Continuity and change of national identity in the German public.] Kölner Zeitschrift für Soziologie und Sozialpsychologie 68 (3):435-456.

Marsh HW et al. (2014) Exploratory structural equation modeling: an integration of the best features of exploratory and confirmatory factor analysis. Annual Review of Clinical Psychology 10, 85-110.

Mayda AM and Rodrik D (2005) Why are some people (and countries) more protectionist than others? European Economic Review 49 (6):1393-1430.

McLaren LM (2003) Anti-immigrant prejudice in Europe: contact, threat perception, and preferences for the exclusion of migrants. Social Forces 81 (3):909-936.

Miller-Idris C and Rothenberg B (2012) Ambivalence, pride and shame: conceptualisations of German nationhood. Nations and Nationalism 18 (1):132-135.

Müller J-W (2009) Constitutional Patriotism. Princeton, NJ: Princeton University Press.

Mulligan K (2013) Variability or moderation? The effects of ambivalence on political opinions. Political Behavior 35 (3):539565.

Mushaben JM (2017) Wir schaffen das! Angela Merkel and the European refugee crisis. German Politics 26 (4):516-533.

Newby-Clark IR, McGregor I and Zanna MP (2002) Thinking and caring about cognitive inconsistency: when and for whom does attitudinal ambivalence feel uncomfortable? Journal of Personality and Social Psychology 82 (2):157.

O'Rourke KH and Sinnott R (2001) The determinants of individual trade policy preferences: international survey evidence. Brookings Trade Forum 157-206.

Pautz H (2005) The politics of identity in Germany: the Leitkultur debate. Race \& Class 46 (4):39-52.

Pehrson S, Vignoles VL and Brown R (2009) National identification and anti-immigrant prejudice: individual and contextual effects of national definitions. Social Psychology Quarterly 72 (1):24-38.

Rankin DM (2001) Identities, interests, and imports. Political Behavior 23 (4):351-376.

Reeskens T and Hooghe M (2010) Beyond the civic-ethnic dichotomy: investigating the structure of citizenship concepts across thirty-three countries. Nations and Nationalism 16 (4):579-597. 
Rivers D (2006) Sample matching: representative sampling from internet panels. Polimetrix White Paper Series. Palo Alto, CA: WebSM. Available at http://www.websm.org/db/12/16408/Web\%20Survey\%20Bibliography/Sample_matching_Repre sentative_sampling_from_Internet_panels/ (accessed 10 December 2018).

Roßteutscher S et al. (2018) Short-term campaign panel 2017 (GLES), data file version 5.0.0. Available at http://dx.doi.org/ 10.4232/1.13047.

Rudolph TJ (2005) Group attachment and the reduction of value-driven ambivalence. Political Psychology 26 (6):905-928.

Rudolph TJ and Popp E (2007) An information processing theory of ambivalence. Political Psychology 28 (5):563-585.

Schildkraut DJ (2007) Defining American identity in the twenty-first century: how much 'there' is there? Journal of Politics 69 (3):597-615.

Shulman S (2002) Challenging the civic/ethnic and West/East dichotomies in the study of nationalism. Comparative Political Studies 35 (5):554-585.

Sides J and Citrin J (2007) European opinion about immigration: the role of identities, interests and information. British Journal of Political Science 37 (3):477-504.

Smith AD (1991) National Identity. Las Vegas: University of Nevada Press.

Smith RM (1988) The 'American creed' and American identity: the limits of liberal citizenship in the United States. Western Political Quarterly 41 (2):225-251.

Sniderman PM, Hagendoorn L and Prior M (2004) Predisposing factors and situational triggers: exclusionary reactions to immigrant minorities. American Political Science Review 98 (1):35-49.

Sniderman PM and Theriault SM (2004) The structure of political argument and the logic of issue framing. In Saris WE (ed.), Studies in Public Opinion: Attitudes, Nonattitudes, Measurement Error, and Change. Princeton, NJ: Princeton University Press, pp. 133-165.

Steenbergen MR and Brewer PR (2004) The not-so-ambivalent public: policy attitudes in the political culture of ambivalence. In Saris WE (ed.), Studies in Public Opinion: Attitudes, Nonattitudes, Measurement Error, and Change. Princeton, NJ: Princeton University Press, pp. 93-129.

Tajfel H and Turner JC (1979) An integrative theory of intergroup conflict. In Austin WG (ed.), The Social Psychology of Intergroup Relations. Monterey, CA: Brooks/Cole Publication, pp. 33-47.

Theiss-Morse E (2009) Who Counts As An American? The Boundaries of National Identity. New York: Cambridge University Press.

Thornton JR (2011) Ambivalent or indifferent? Examining the validity of an objective measure of partisan ambivalence. Political Psychology 32 (5):863-884.

Trauner F and Turton J (2017) 'Welcome culture': the emergence and transformation of a public debate on migration. Österreichische Zeitschrift für Politikwissenschaft 46 (1):33-42.

Wagner $\mathbf{U}$ et al. (2012) A longitudinal test of the relation between German nationalism, patriotism, and out-group derogation. European Sociological Review 28 (3):319-332.

Weldon SA (2006) The institutional context of tolerance for ethnic minorities: a comparative, multilevel analysis of Western Europe. American Journal of Political Science 50 (2):331-349.

Williams R (2010) Fitting heterogeneous choice models with oglm. Stata Journal 10 (4):540-567.

Wittlinger R (2010) German National Identity in the Twenty-First Century: A Different Republic After All? Basingstoke: Palgrave Macmillan.

Wright M, Citrin J and Wand J (2012) Alternative measures of American national identity: Implications for the civic-ethnic distinction. Political Psychology 33 (4):469-482.

Wright $\mathbf{M}$ and Reeskens $\mathbf{T}$ (2013) Of what cloth are the ties that bind? National identity and support for the welfare state across 29 European countries. Journal of European Public Policy 20 (10):1443-1463.

Zaller J and Feldman S (1992) A simple theory of the survey response: answering questions versus revealing preferences. American Journal of Political Science 36 (3):579-616.

Zimmer O (2003) Boundary mechanisms and symbolic resources: towards a process-oriented approach to national identity. Nations and Nationalism 9 (2):173-193.

Cite this article: Lindstam E, Mader M and Schoen H (2021) Conceptions of national identity and ambivalence towards immigration. British Journal of Political Science 51, 93-114, https://doi.org/10.1017/S0007123418000522 